\title{
METODOLOGICZNA STRONA DZIEŁA „OSOBA I CZYN“
}

Nie będzie zapewne błędem, gdy powiem, że książka Osoba i czyn narodziła się z potrzeby syntezy. Chodziło o syntezę myślenia o osobie właściwego dla nurtu arystotelesowsko-tomistycznego z nurtem fenomenologicznym, przy czym w nurcie tym szczególnie preferowaną okazuje się metoda eidetyczno-opisowa, którą posługiwał się M. Scheler, a u nas R. Ingarden. Synteza fenomenologii i tomizmu dotyczy przede wszystkim jednego punktu: teorii aktu i możności. Autor pisze: „Sam w sobie czyn jako actus humanus winien dopomóc w umysłowej i poznawczej aktualizacji tej potencjalności, którą zakłada i która znajduje się u jego korzenia. Jest to zaś potencjalność bytu osobowego, sam zaś czyn nie tylko tłumaczy się jako actus humanus, ale jako actus personae. Tak więc na samym początku dociekań idących $\mathrm{w}$ kierunku poznania osoby poprzez czyn musimy stwierdzić, że bynajmniej nie rezygnujemy z tej kapitalnej intuicji filozoficznej, która jest niezastąpiona, gdy chodzi o zobiektywizowanie wszelkiego dynamizmu, a więc także i dynamizmu czynu czyli działania świadomego. Chodzi o możliwie pełną i wszechstronną obiektywizację tego dynamizmu, gdyż tylko tą drogą możemy wydobyć na jaw całą rzeczywistość osoby" (s. 31).

Aby synteza tego rodzaju mogła się powieść, trzeba było podjąć zadanie podwójnej interpretacji: interpretacji wybranych tez filozofii tradycyjnej (tez o osobie, o akcie, o możności) oraz tez pochodzących z fenomenologii. Celem interpretacji jest ukazanie, w jaki sposób tezy te się postulują, podtrzymują, uzupełniają.

Byłoby jednak dużym uproszczeniem, gdyby całą pracę Osoba $i$ czyn rozważać wyłącznie pod kątem potrzeby syntezy. Sądzę nawet, że to nie potrzeba syntezy decyduje o jej oryginalności i wartości. Praca jest czymś zdecydowanie więcej, niż tylko interpretacją tez fenomenologii i tomizmu. Uwzględniając wyłącznie jej „fenomenologiczną" stronę, trzeba powie- 
dzieć, że zawiera ona mnóstwo analiz fenomenologicznych, inspirowanych bardzo własnym sposobem widzenia świata i ludzi. Istotny rys tego widzenia zdaje się oddawać słówko „uczestnictwo”. Osoba „uczestniczy w bycie", tak jak czyn osoby ,uczestniczy” w rzeczywistości osoby, z kolei czyn osoby daje osobie możność uczestniczenia w budowanej przez miłość wspólnocie osób. W teorii uczestnictwa, którą rozwija Osoba i czyn możemy widzieć jakąś formę przezwyciężenia subiektywizmu i indywidualizmu, lansowanego przez niektóre współczesne filozofie świadomości, również inspirowane fenomenologią. Jak widać, chodzi nie tylko o filozofię. W ostatecznym rozrachunku idzie o styl chrześcijańskiej praxis. Zakończenie pracy wskazuje na przykazanie miłości. Przykazanie to jest jej ostatecznym zwieńczeniem. Autor pisze: „Przykazanie »będziesz miłował uwydatnia przede wszystkim jasną stronę rzeczywistości ludzkiego działania i bytowania "wspólnie z innymi«" (s. 325). Chodzi zatem także o przezwyciężenie izolacjonizmu i indywidualizmu w sposobie bytowania chrześcijanina. Głęboko brzmią przy tym słowa: ,jasna strona rzeczywistości ludzkiej”. „Jasność” przebija poprzez wszystkie karty dzieła. Dzieło jest o ,,jasnych stronach” człowieka. To w nich szuka Autor autentycznego obrazu istoty ludzkiej. Oprócz pojęć ,osoba”, ,akt”, „możność" ta swoista ,jasność" jest cennym spadkiem po tomistyczne: tradycji. Odcina ona w sposób zasadniczy książkę od licznych prac na temat człowieka, które przyniósł nam egzystencjalizm. Świadectwo dawane tej jasności na kartach książki przemawiało do mnie najgłębiej podczas lektury. Osoba to Dobro. Książka jest świadczeniem osobie rozumianej jako Dobro.

Nie jest łatwo pisać na temat takiej książki. Wyraża ona niezwykle osobisty choć zarazem stylowo całkowicie, ,zobiektywizowany" sposób spotkania ze współczesnością człowieka mocno w tę rzeczywistość wtopionego. Dla Polaka ma całkiem swoiste znaczenie kluczowa idea książki, że osoba wypowiada się w czynie i poprzez czyn, że czyn, poprzez który człowiek wchodzi w uczestnictwo, jest najwyższym prawem człowieka, częścią jego żyjącej duszy, w tym miejscu czasu i historii, w jakim się znalazła, ma cenę szczególną. Tak odczuwam również akceptację podstawowych idei tomizmu. Rzecz idzie nie tylko o tomizm, ale o sens stosunku do tradycji, który w czasach przełomu zawsze jest problemem. Kiedy się widzi to wszystko, tym trudniej jest pisać, jeśli oczywiście pisząc, chce się coś powiedzieć a nie tylko przepisywać rzeczy napisane. Decydując się na pisanie i decydując się na pełną akceptację podstawowych intencji Autora, nie można jednak przemilczeć tego, co towarzyszyło czytaniu: doświadczenia jakiegoś niedosytu. Chciałbym obecnie poddać to doświadczenie niedosytu jakiejś artykulacji i jakiemuś usprawiedliwieniu. 
$\mathrm{Z}$ pewnością nie był to niedosyt syntezy. Autor osiągnął $\mathrm{w}$ tej dziedzinie coś, co się liczy: wzbudził zaufanie do metod współczesnej filozofii i do wyników jakie osiąga ona na gruncie filozofii człowieka. Książka otwarła i nadal będzie otwierać drzwi do współczesności tym, którzy swe przywiązanie do filozofii związali z równym przywiązaniem do tradycji. Więc o jaki inny niedosyt chodzi? Dla mnie był to niedosyt samoistnych badań nad szeregiem konkretnych zagadnień. Troska o końcową syntezę sprawia, że nasze analizy ucinamy przedwcześnie, często wtedy, gdy u czytelnika ciekawość dopiero się zaostrza. Znał to niebezpieczeństwo wielki mistrz syntezy św. Tomasz z Akwinu, gdy każdą ze swoich kwestii zaczynał stwierdzeniem ,,videtur quod non”, znał je także Descartes, gdy proponował swe wątpienie metodyczne, i Husserl, gdy wystąpił ze swym fenomenologicznym epohé. Epohé stało się zresztą bazą wyjściową całej fenomenologii, także tej Schelerowskiej. Oczywiście nie przesądzało ono o końcowym stosunku do tradycji. Wiemy, że koniec końcem wszyscy fenomenologowie dochodzili do jakiegoś z nią porozumienia. Epohé powodowało jednak coś bezcennego: jakieś „wyzwolenie wyobraźni” i idący $\mathrm{z}$ niego radykalizm $\mathrm{w}$ formułowaniu pytań, dla którego jedyną instancją było doświadczenie. Jeżeli jednak decydujemy się, aby wyjść od tradycji (obieramy np. postawę epohé w stosunku do przesądów dotyczących tradycji), to wtedy powstaje pytanie: o którą tradycję chodzi? Tradycja to rzecz złożona. Czy nurt arystotelesowsko-tomistyczny jest tym najwłaściwszym, gdy idzie o filozofię człowieka? Czy tradycja augustyńska nie byłaby w tym miejscu bardziej pouczająca?

Przyznam, że najwięcej kłopotów sprawiają mi związane z książką zagadnienia metodyczne. Zdaję sobie sprawę $\mathrm{z}$ tego, jak zwodniczą rzeczą jest metodologia. Często jest tak̆, że metoda nie tłumaczy wyników a wyniki nie chcą się zmieścić w metodzie. Husserl zbudował transcendentalną fenomenologię, ale nie wyjaśnił do końca, na czym polega metoda transcendentalna. Kto bada np. metody zbierania grzybów, ten może nie znaleźć ani jednego grzyba a nawet dojść do sceptycyzmu, gdy idzie o istnienie grzybów. Autor nazywa swą metodę „redukcją”. Pisze: „Tłumacząc, idziemy coraz dalej za przedmiotem, który dany jest nam w doświadczeniu - i tak, jak nam jest on dany" (s. 20). I dalej: ,...c h odzi ... o wniknięcie w rzeczywistość realnie istniejącą. Racje tłumaczące tę rzeczywistość zawarte są w d oświ adczeni u" (s. 21). Wydawałoby się, że jesteśmy bez reszty w orbicie fenomenologii. Pod zaproponowaną nam metodę podpada bowiem zarówno Schelerowski opis eidetyczny, Husserla analiza transcendentalna i analiza intencjonalnych założeń aktu rsp. doznania, a także analityka rsp. hermeneutyka Dasein, którą operuje Heidegger. Jest jednak poważny kłopot. Wiodącą nicią opisów fenomenologicznych jest naj- 
częściej szeroko pojęte to, co jakościowe. Istotę upatruje się najczęściej w jakościowym uposażeniu rzeczy. Czy w obrębie tak pojętej istoty wykryjemy coś takiego jak „możność”, „akt”, „osoba” filozofii tomistycznej? Najpierw wydaje mi się, że w tomiźmie są to rzeczywistości całkowicie pozafenomenalne. Owszem pewne elementy treściowe tych rzeczywistości są dostępne doświadczeniu bezpośredniemu, ale są to tylko jakieś elementy. W istocie rzeczy są to rzeczywistości pozafenomenalne, meta-fizyczne. (Znamienne jest tutaj ujęcie osoby. Autor nie wydaje się być zdecydowany. Pisze: „,... nie trzeba nikomu wykazywać czyli udowadniać, że człowiek jest osobą" i dalej: „Jasną jednak jest rzeczą, iż osoba ... jest poza-świad om ościową rzeczywistością", s. 19 i 161). Osoba jako „racja tłumacząca" wykracza zatem poza sferę metody fenomenologicznej. Po drugie pojęcia te zawierają element istnienia. Jak przejść od metody, która chwyta to, Co jest, do metody, która chwyta to, Że jest? Jedynym fenomenologiem, który stara się rozwiązać ten problem, jest Heidegger. Jest rzeczą znamienną, iż intencje Kardynała Wojtyły i intencje Heideggera są zbieżne. Jednemu i drugiemu chodzi o jakieś ,osadzenie w bycie” człowieka. Ale Heidegger, aby ten zamiar zrealizować, czuje się zmuszony sięgnąć aż do Parmenidesa. Sądzi, że ani pojęcie aktu i możności, ani pojęcie osoby, tej funkcji nie spełnia, są one bowiem obce tej najpierwotniejszej treści człowieczeństwa w człowieku. Filozofia tomistyczna była filozofią istnienia.Filozofia Husserlowska była filozofią świadomości. Jak przejść od jednej do drugiej? Prosta juxtapozycja nie wystarczy, bo ona niczego nie tłumaczy. Dla tomistów uznanie człowieka za osobę oraz uchwycenie jej pod kątem aktu i możności nie wnosi nic nowego, ponieważ o akcie i możności od początku wiadomo, że musi (jako pojęcie typu metafizycznego) realizować się wszędzie. Dla fenomenologów powstaje groźba „,reifikacji człowieka”, groźba ,przymierzania” do ludzkiej specyfiki kategorii wziętych z tego, co nieludzkie. Dla jednych i drugich problemem jest korelacja metod: jak się mają do siebie ich wyniki, jak i gdzie się zakładają, jak i gdzie się postulują. Przejście od ,,jakości” do ,istnienia”, to $\mathrm{m}$. in. problem Heideggera. Jeśli przejście to okazało się dzięki niemu możliwe, to powstaje kłopot stosunku do tradycji: to nie osoba, akt, możność, substancja były tu pomostem.

Można również mieć wątpliwości, czy droga poprzez czyn jest tą najwłaściwszą drogą dojścia do prawdy o człowieku. Rozumiem, że pojęcie czynu jest tu wzięte dość szeroko. Rozumiem również to, o jaki czyn chodzi. Bardzo żywo odczułem te fragmenty książki, w których Autor podkreślał aksjologiczny charakter czynu osoby. Jeżeli jednak tak jest, to droga do prawdy człowieka wiedzie nie tyle poprzez czyn pojęty jako akt, ale poprzez wartość, w imię której osoba podejmuje swe czyny lub 
godzi się ich zaniechać. Myślę, że czym innym jest rzeczywistość osoby, a czym innym jest poznanie osoby. Rzeczywistość osoby eksploduje w czynie, ale poznanie osoby może kroczyć całkiem niezależnymi ścieżkami.

Wydaje mi się, że w akcentowaniu aksjologicznych wymiarów osoby i jej czynu kryją się pewne niewyczerpane do końca założenia. Otwiera ono drogę do emocjonalnego sposobu poznania człowieka. To nie „racjonalna redukcja", wyjaśnianie lub tłumaczenie, otwiera nam wnętrze człowieka. Mówił o tym szeroko Scheler, ostateczne konsekwencje filozoficzne wyciągał z tego Heidegger. Rzecz w tym, że filozofia współczesna zdaje się tutaj w sposób niezwykle zasadniczy kwestionować uprawnienia epistemologii arystotelesowsko-tomistycznej $\mathrm{w}$ dziedzinie myślenia o człowieku. Dokonuje się to pod hasłem krytyki idei człowieka jako animal rationale. Jesteśmy świadkami kryzysu tradycyjnej wersji racjonalizmu na rzecz wersji całkiem swoistej (która nie jest jednak irracjonalizmem). Tak więc stajemy wobec kluczowego zadania: należy bądź zreinterpretować tradycyjne pojęcie racjonalizmu, bądź odciąc się od nurtu epistemologii „emocjonalnej”. Jeśli zgodzimy się na ów nurt i uda się nam ukazać, że nie jest on obcy Tomaszowi, wtedy to ni e doświadczenie czynu będzie treścią wiodącą naszych badań człowieka. Doświadczenie to jest bowiem zbyt ambiwalentne. Czyn wypły wa ze źródeł, które nie są czynem. W tych źródłach trzeba nam szukać człowieka.

I jeszcze jedno wrażenie niedosytu: brak analiz czas ow ego wymiaru człowieka. Nie chodzi oczywiście o jeden więcej rozdział, lecz o problem staw a nia się osoby. U Schelera, Husserla, Heideggera „osoba" jest tym, co się staje. W tomiźmie osoba jest. Wydaje mi się, że pominięcie zagadnienia czasowości rsp. wewnętrznej świadomości czasu sprawiło, że spór między obydwoma stanowiskami nie został rozstrzygnięty.

Różne mogą być reakcje na wrażenie niedosytu. Wydaje mi się, że bezdyskusyjnym walorem książki jest inspiracja. Jej miejsce w polskiej filozofii chrześcijańskiej jest jasno określone: $\mathrm{z}$ jednej strony $\mathrm{z}$ a m y k a ona jeden $\mathrm{z}$ ważnych etapów wypełnionych potyczkami tej filozofii ze współczesnością, aby z drugiej strony przez swą inspirację ot w or zyć etap następny. 